\title{
Sweetening the Deal
}

\author{
To what Extent can Public Funding \\ Attract Private Film Investors?
}

\author{
Terje Gaustad
}

\begin{abstract}
Various forms of public funding are used to encourage national film production, and one important quality of such funding is its ability to attract complementary private financing and thus maximize the resources available for national film. When the Norwegian government restructured its film support system in 2001, it was an explicit goal to attract more private investments into national films. Yet three years later, the government observed that while many national films now could show a healthy return on their private capital of more than 50 percent, there seemed to be a notable lack of participation from the traditional investment community in the financing of these films. The present article explores the economic reasons for the lack of involvement by applying project financing and transaction cost perspectives to a microanalysis of the financing and performance of all Norwegian films released theatrically in 2005 .
\end{abstract}

Keywords: film policy, public funding, film financing, film performance, financial risk, risk management

\section{Introduction}

Every European country supports its film industry through various forms of public funding where the majority of funds are allocated to film production (Le Floch-Andersen 1999), and European films are typically made with a mix of public and private financing. Public funding not only has a direct effect on the resources available for film production, but also an indirect effect on a given production's ability to attract complementary private financing. Consequently, the linkage between public and private financing is a key element in film policy.

Public support of the film sector is seen as particularly important in smaller countries where the market for national films is limited by language and culture, and the various public support schemes in these countries will thus be instrumental to filmmakers' ability to attract private finance. Norway, with its population of 4.7 million (SSB 2008) and total annual cinema admissions of around 12 million (Film\&Kino 2007), serves as a good case for studying the relationship between public funding and private film financing in smaller countries.

This codependent relationship has been explicitly recognized by the Norwegian government. In a major revision of its film policy in 2001, one of the key goals was to 
increase private investments in Norwegian films, and in 2007 this goal was restated in a white paper to the parliament (St.meld.nr.22, 2006-2007). The white paper also called attention to the need for a predictable public funding system designed to encourage private investments, thus acknowledging the importance of public funding as a tool for reaching the goal of increased private investments.

Addressing the issue three years after implementing the new policy, the Norwegian Ministry of Culture and Church Affairs noted that while many of the recent national films could show a healthy return on their private capital of more than 50 percent, there seemed to be a notable lack of participation from the traditional investment community in the financing of these films (St. meld. nr. 25, 2003-2004). Private investments were typically only made by industry insiders such as producers and distributors. On the one hand, the new public funding policy seemed successful because a number of films could show strong returns on private capital, but on the other hand, it seemed less successful because it still did not attract investments from professional investors outside the industry.

The present article explores the economic reasons for the lack of outsider investments, applying project financing and transaction $\operatorname{cost}^{1}$ perspectives. It begins with a discussion of film financing as an application of general project financing with an emphasis on the use of layered financing and its waterfall recoupment structure. Later it presents the financing and performance of all Norwegian films released theatrically in 2005. This empirical micro-analysis is primarily based on documentation provided by the Norwegian Film Fund, the main body handling financial film support on behalf of the government, which was involved with all the 2005 films and thus possessed a unique and somewhat standardized set of financing and performance data for each film. The documentation was supplemented with in-depth interviews with producers responsible for the financing, covering seven of the total nineteen films. Finally, the challenge of attracting outsider investments is discussed in light of the empirical findings.

\section{Film Financing}

The financing of Norwegian theatrical feature films, most independent films internationally and to a large extend also Hollywood studio films is best understood in terms of project financing ${ }^{2}$. Generally, project financing is used when a particular facility or a related set of assets is capable of functioning profitably as an independent economic unit (Finnerty 1996). In the case of film financing, the feature film itself constitutes this set of assets. Project funds are used to create a film with supporting materials such as trailers and other marketing materials that when completed will be exploited to generate a cash flow from which project financing can be serviced.

A project will have one or more sponsors who initiate it. These project sponsors, other providers of funds, as well as the financially responsible parties providing credit support and security arrangements must agree to make available all funds necessary to complete the project. In the film financing case, the sponsors are the producers who initiate the film projects. Together with the film's investors, they must ensure that enough funds are available to finish the film before they commence production. Investors will often require various security arrangements such as cast and crew insurances and completion bonds. When contracted, the completion bond company is responsible for providing additional funds to see the film completed in case the production runs over budget due to various 
unforeseen events. It thereby ensures completion of the film to the other project parties (Rudman and Ephraim 2004).

Furthermore, the parties have to agree and ensure that when project completion occurs and operations commence, the project will have available sufficient cash to enable it to meet its operating expenses and debt service requirements. Completion of the film project occurs when the film is delivered to its distributor with all supporting materials and paperwork. The distributor will then exploit the film in all possible media and markets, and this exploitation represents the operation of the project. Typically the distributor will provide or otherwise be responsible for the funds necessary to carry out the exploitation (Cones 1997). By contracting a distributor on such terms before commencement of production, the producer may ensure that sufficient cash flow will be available for exploitation of the film.

As in conventional direct financing, the basic categories of project finance are debt and equity, but while direct financing investors will look to the firm's entire asset portfolio for security and servicing of the investments, project financiers may only look to the project-related assets and cash flow. The critical distinguishing feature of project financing as opposed to direct financing is that the project is treated as a distinct legal entity. Project assets, project-related contracts, and project cash flow are segregated to a substantial degree from the sponsoring entity.

Figure 1 illustrates the basic elements of film project financing. At the center is a related set of assets constituting the film ${ }^{3}$. It must include all the facilities that are necessary to constitute an economically independent, viable operating entity; that is all elements necessary to complete delivery of the film to the distributors, which represent the project's purchasers. Purchase contracts take the form of distribution contracts and the project's output is the various distribution rights to the film ${ }^{4}$.

Suppliers are the wide range of creative and technical personnel as well as service providers and suppliers of raw materials ranging from film stock to set construction materials. These are contracted by the project entity to provide all input necessary to complete the film.

Figure 1. The Basic Elements of Film Project Financing

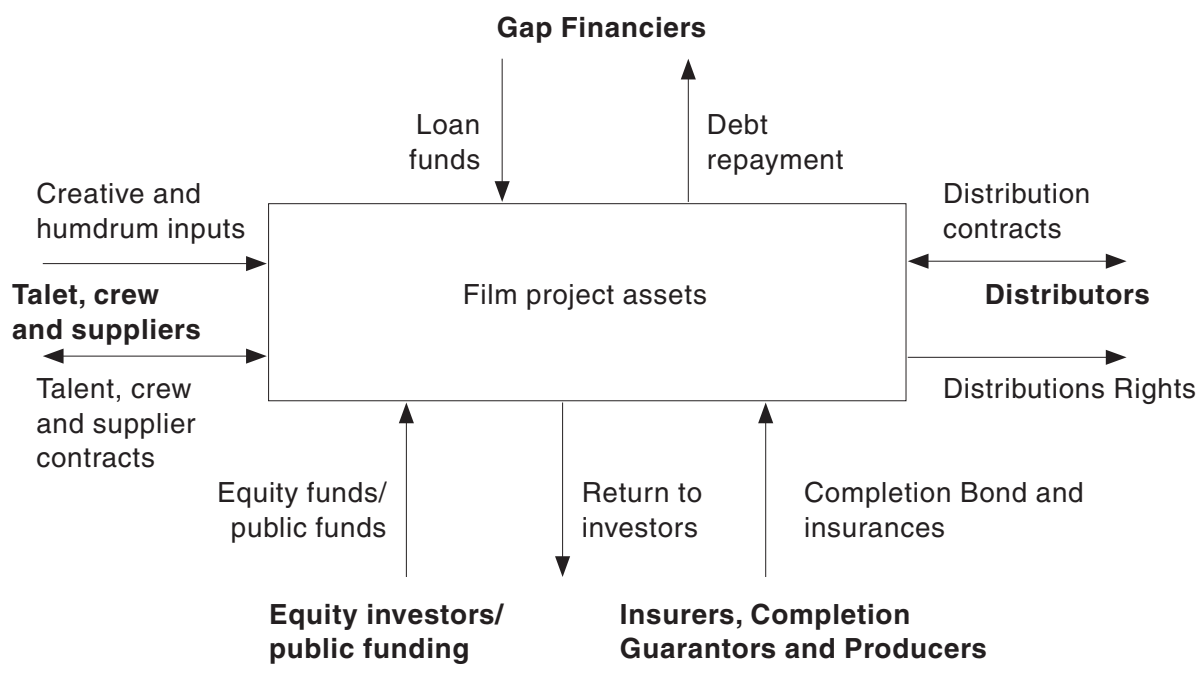


The film producers must reach financial closure ${ }^{5}$ by securing sufficient funds - debt and equity - for production and operations. The debt and equity elements of project financing are tailored to the characteristics of the project, and key factors are the nature of project cash flow and the collateral value of the project's assets. For a film project, there will typically be a very high degree of uncertainty in predicting the level of cash flow generated from its exploitation. The demand for a specific feature film will always be uncertain up until the point at which one can place the finished film in front of its buyers. It may be a commercial success, generating revenues far exceeding its costs, but it may also flop, finding very few buyers who place any positive value on it. Research carried out by DeVany and Walls (1999) shows that films are among the riskiest products, as the probability distribution of their theatrical earnings or box-office has infinite variance.

The collateral value of the film project's assets is affected by this uncertainty. Before the project is completed and the film released, the collateral value will generally be low because nobody can guarantee that the film will not flop. In cases where a film performs poorly in the market, the collateral value is furthermore affected in a negative direction due to the very high degree of asset specificity for most of the assets created in a film project. High asset specificity means that the assets cannot be redeployed outside the context of the project without sacrificing productive value. Most of the assets are unique to the project. Footage shot for one film is seldom of any value whatsoever to other film projects, so the film it is shot for has to perform well for it to have any value.

Generally, the level of uncertainty associated with a project's ability to generate cash flow and the collateral value of its assets are reflected in its optimal debt-equity ratio. Typically, higher-risk projects take more equity to protect the interest of lenders, while lower-risk projects can accommodate more debt (Merna and Khu 2003). One would thus expect to find very high equity shares in film project financing compared to other types of projects offering less market uncertainty and higher collateral value. While, for example, toll-road projects may see debt-equity ratios around 95-5 (Merna and Khu 2003), independent feature films made for the international market seldom see more than 20-80 (Pendreigh 2003).

\section{Layered Finance}

Achieving financial closure is always difficult, not only for film projects, and all project financing thus requires careful financial engineering to allocate the risks and rewards among the involved parties in a manner that is mutually acceptable. It is often necessary to find financing structures that offer more than the two basic layers of debt and equity. This allows the project sponsor to provide a larger group of different investors with instruments that match the risk/return characteristics best suited to their appetites and requirements. The increased pool of potential investors then available may allow the project sponsor both to close the financing and to reduce its cost of capital.

Layered financing can generally be applied to both debt and equity by adding one or more layers of subordinated debt and preferred stock (Parra and Kahn 2001), as shown in Figure 2 below. When subordinated debt is used, the senior lender agrees to lend to a project because, relative to the subordinated lender(s), the subordination provides it with priority rights to both debt servicing and security. In return for ceding these rights to the senior lender and assuming greater risk, the subordinated lender benefits from the higher yield. 
Figure 2. Layered Project Financing

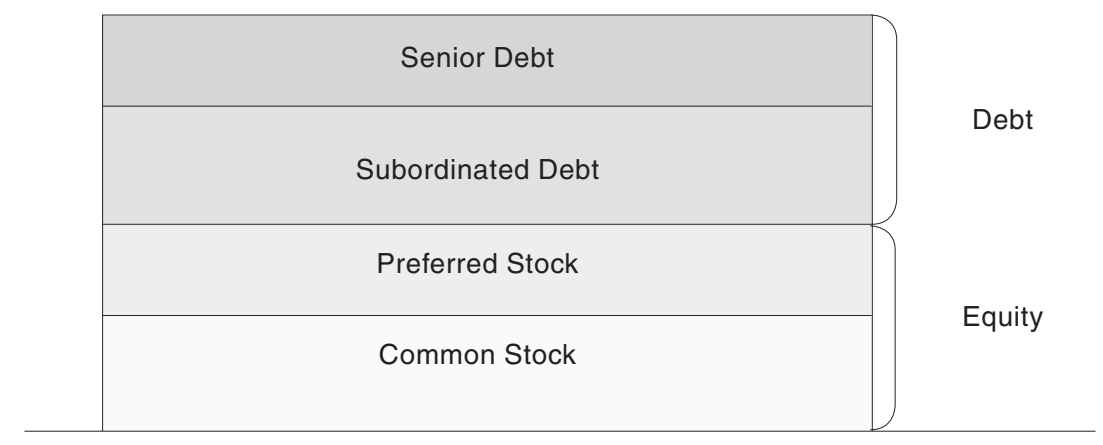

Parra and Kahn (2001) recognize three general categories of project partners that are typically willing to take a subordinated position:

- First, a project "insider" may become a subordinated lender to substitute debt for required equity. Among such insiders are project sponsors, service providers and other parties whose primary motivation is to ensure the sale of their product or service to the project vehicle.

- Second, an "investor" not otherwise affiliated with a project or its sponsors but desiring to make an investment in the project because of its profit-making potential may also choose to become a subordinated lender to characterize its investment as debt rather than equity. Typically, these investors purchase project convertible (subordinated) debt and seek profits available from the conversion of their debt to equity if the project is successful.

- Third, a project "catalyst", a party unaffiliated with a project or its sponsors or investors that desires to promote investment in a country or region, may choose to become a subordinated lender by providing subordinated loans in amounts sufficient to motivate commercial lenders to participate as senior lenders in a given project's funding.

In film finance, the first category is a common ingredient in a project's financing plan. Producers and key personnel as well as service providers often defer part of their fees to be recouped in a subordinated position. Furthermore, some investors, matching the second category, tend to accept lower priority in return for a larger share of the film's potential upside. And finally for the third category, public funding bodies, whose prime motivation may be either to see national films produced or to attract filmmaking activity to their region, provide subordinated funding to help producers close financing on films that coincide with these goals.

The line between debt and equity can sometimes seem blurry in film finance, as equity investors do not necessarily obtain an ownership share in the special purpose company set up for the film, if any, or in the film's copyright. However, investors who acquire a share in the film's potential profits are typically considered equity investors while those earning interest, either at an ongoing rate or defined as a fixed markup on the funds provided, are considered lenders. 


\section{Common Elements of Independent Film Finance}

The different elements of layered debt and equity finance found in any film project will depend on the film's characteristics and qualities as well as on the institutional environment within which it is produced. However, for so-called independent films ${ }^{6}$ there is a set of elements that are commonly utilized. These are minimum guarantees, gap loans, equity and deferments, and for most European productions public funding may also be added as a fifth element.

Minimum guarantees (MGs) are advances paid by distributors against the producer's share of revenues generated by the distributor from exploiting the film. If the finished film should perform worse than anticipated when the MG was agreed and paid out so that the producer's share of revenues ends up below the MG amount, the difference will not be repayable to the distributor - thus the term minimum guarantee (Cones 1997, 1992; Baumgarten et al. 1992).

Gap loans are senior debt loans fully repayable from first revenues received by the producer. The specific terms for different gap loans vary, but they are typically limited recourse loans secured in the producer's share of revenues, i.e. the cash flow generated by the film that is paid out from its distributors to the producer.

Equity includes all cash investments made in consideration for a share of the film's profit. Sometimes an equity investment entitles the investor to a share ownership in the film's copyright or in the special purpose company that produces and owns the film, but often the "ownership" is limited to a contractual share of revenues from which the investor may see the return of and on the investment.

Deferments are all or portions of salaries or compensation for cast, crew and suppliers paid on a delayed basis out of the film's revenues. The payment is thus contingent upon the film earning enough to pay it. A film project may have more than one class of deferred compensations, where one class may be subordinated to other deferments as well as other elements in the film financing.

Public funding provided by various public funding bodies through different public funding schemes is typically subordinated to all other financing elements, and in some cases the funding is non-recoupable. Public funding bodies will typically not require any share of profit or other form of ownership in return for the funding, so the public funding element of the financing is generally best described as deeply subordinated debt.

One possible layered financing structure of a film project containing these five common elements is illustrated in Figure 3 below.

\section{Cash Flow and Waterfall Recoupment}

The gross income or cash flow generated from the operation of a project is allocated to cover its operational costs, servicing of the debt and eventually repayment of the debt. In the traditional corporate form of organization, the management and board of directors decide how the cash flow is allocated, but when project financing is used the specific allocation of cash flow is governed in the project financing documents. The rules for how cash flow is allocated must thus be agreed upon by all parties with an interest in the cash flow before financial closure can be reached.

In what order and priority the cash flow is allocated varies from project to project, but typically the operating expenses are covered ahead of debt service and recoupment. 


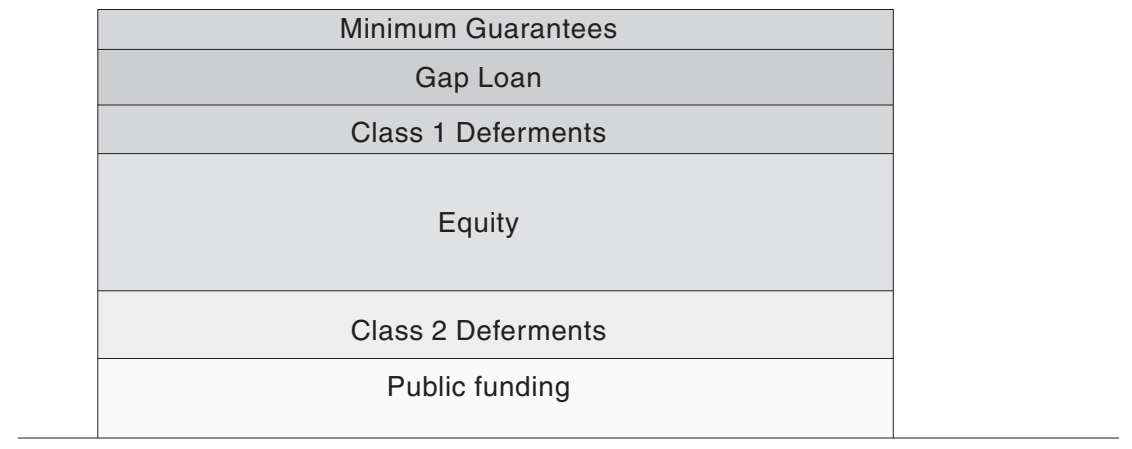

What is left after operating expenses and lenders have been covered is referred to as free cash flow, and all free cash flow is usually distributed to the project's equity investors (Finnerty 1996).

For a general project, a typical order of priority for the project cash waterfall may thus look like this (Parra and Khan 2001):

1. Operating expenses

2. Senior debt service

3. Senior debt service reserve accounts

4. Subordinated debt service

5. Subordinated debt service reserve accounts

6. Restricted payments

Any free cash flow available when these elements are covered allows equity investors to recoup their investments and possibly earn a profit.

In a film project, the cash waterfall is most often specified in the film's net profit definition or net proceeds definition. In addition to defining how the film's revenues will be allocated, this document typically also incorporates the gross receipts definition, which states exactly what kind of revenues should be calculated into the cash flow being allocated. While the definition of the elements to be recouped from the gross receipts and their order vary from film to film, a typical but simplified order of priority for the film project cash waterfall may look like this (Cones 1997; Baumgarten et al. 1992):

1. Distribution fees and expenses

2. Distributor's minimum guarantee

3. Gap loan ${ }^{7}$

4. Class 1 deferments

5. Equity

6. Class 2 deferments 
After the operating expenses (distribution fee and expenses) are covered, the cash flow is allocated to recoup the financing elements in the priority order given by the film's layered financing structure illustrated in Figure 3 above. In this case, the public funding is non-recoupable, so no cash flow is allocated for it. Because the equity investors have already recouped their investments in fifth position, any free cash flow available when these six elements are covered represents profit for the equity investors.

The allocation of revenues as per a waterfall similar to the case above is illustrated in Figure 4 below. The only difference here is that there are no class 1 deferments, but only one class that is subordinated to other debt as well as equity. From the total gross receipts represented by the first pillar, the film's distribution fees and expenses are deducted off the top. From the remaining monies, the distributor recoups its minimum guarantee, thereafter the gap loan is repaid, and so forth until all financing elements are recouped and free cash flow following operating expenses represents net profits.

Figure 4. Waterfall Recoupment

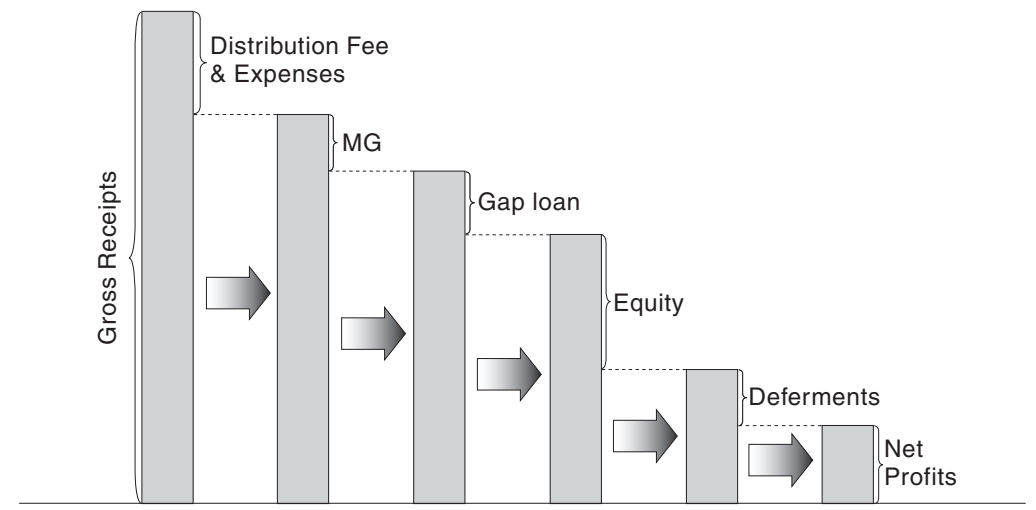

The allocation of economic risk between the film financing participants is easily illustrated by assuming that the film only earns half the revenues illustrated in Figure 4 above. This is shown in Figure 5 below, where only the clear part of the first pillar above the new base line represents gross receipts earned by the film. Distribution fees and expenses will be covered as before, as will the distributor's MG and the gap financier's loan, but there will only be cash flow available to recoup a minor share of the equity investments. At this reduced revenue level, no deferred payments can be made and the film will not earn any net profits. While the equity investors would have recouped their investment with a significant profit at the revenue level illustrated in Figure 4, they would take a significant loss if gross receipts were reduced to half, as illustrated in Figure 5. However, the distributor and gap financier providing debt finance carrying much lesser risk would not be affected by the shift in revenues.

\section{The Norwegian 2005 Films: Finance}

The total number of Norwegian feature films released theatrically in 2005 was 19, of which four were documentaries and fifteen fiction ${ }^{8}$. The budgets or required financing for these films ranged from NOK 2.9 million to NOK 22.8 million. The average budget 


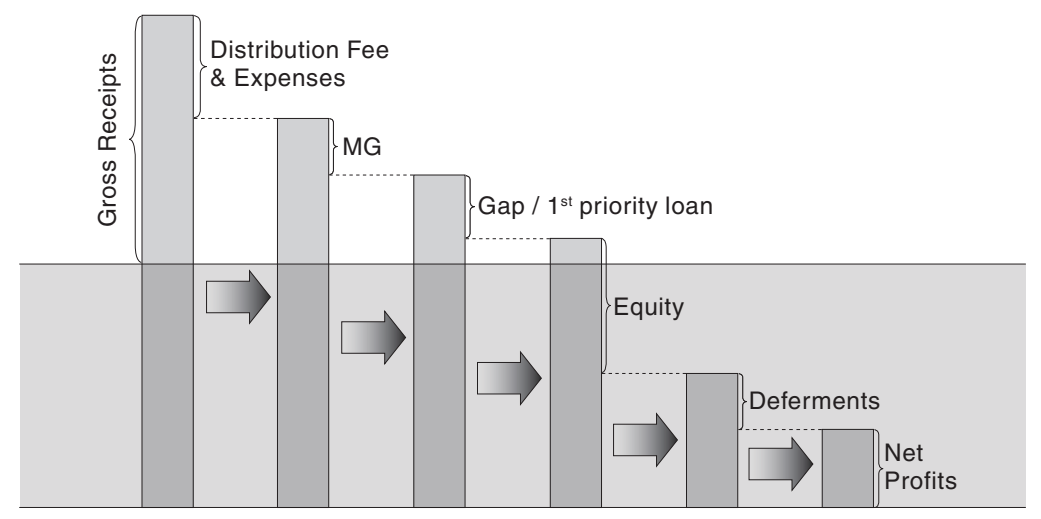

was NOK 14.4 million, but this number is heavily influenced by a few very low-budget films. The majority of films were budgeted at NOK 15 million or more; see Table1.

The total budgets include both production and P\&A costs. All the costs required to assemble the film up until it is ready for delivery to the distributor are defined as production costs, and these included development costs (screenplay, budgeting, etc.), cost of principal photography (actors, film stock, etc.) and post-production costs (editing, music, etc.). P\&A costs are the 'print and advertising' costs incurred to make the film available for the audience. As indicated by the term, they include both copying ('print') and marketing ('advertising') costs. On average NOK 11.9 million was spent on production while NOK 2.4 million was spent on $\mathrm{P} \& \mathrm{~A}^{9}$.

\section{Public and Private Finance}

The financing of all the films included both public and private funds. The dominant source of public funding was the Norwegian Film Fund. The fund's production financing support is mainly channeled through two systems: One where the review process and funding decision are handled by one of its film consultants, who assesses both the film's artistic and economic viability, and one where the funding decision is made primarily based on the film's projected market potential. For both systems the Fund expects part of the budget to be financed by private sources, but while the private share of the finance may be as low as 20-30 percent of the budget under the consultant system, the Fund requires at least 50 percent private funding before it will consider a film under the market review system.

Other sources of public funding included the Nordic Film and TV Fund, which provides production funds for films with theatrical distribution in at least two Nordic countries; Eurimages, which supports European co-production; as well as smaller contributions from various other Norwegian public funding bodies.

For the average film, 44 percent of the total budget was financed by the Film Fund and nine percent by other public funding sources. The balance 47 percent was financed by private sources (see Table 2 ). In relative terms, the private capital financing was strongest for the P\&A, where it covered 64 percent of the funding. The combined public funding was strongest in both relative and absolute terms for the production, where it covered 56 percent of the costs. 
Table 1. The 2005 Films: Budgets

\begin{tabular}{lrrr} 
Title & Production & Distribution & \multicolumn{1}{c}{ Total } \\
\hline $100 \%$ Human (100\% mennekse) & $2,460,318$ & 404,000 & $2,864,318$ \\
37 and a Half (37 $1 / 2$ ) & $15,187,716$ & $4,500,000$ & $19,687,716$ \\
Too Much Norway (Alt for Norge) & $16,120,000$ & $1,650,000$ & $17,770,000$ \\
Love me Tomorrow (Elsk meg i morgen) & $14,896,507$ & $3,763,000$ & $18,659,507$ \\
An Enemy of the People (En folkefiende) & $18,000,000$ & $2,615,940$ & $20,615,940$ \\
Factotum (Factotum) & $17,412,482$ & $2,882,224$ & $20,294,706$ \\
The Giant (Giganten) & $5,436,365$ & $2,582,600$ & $8,018,965$ \\
Import Export (Import og eksport) & $16,998,769$ & $2,292,126$ & $19,290,895$ \\
Izzat (Izzat) & $16,910,233$ & $3,353,500$ & $20,263,733$ \\
Le Regard (Blikket) & $10,824,811$ & $1,500,000$ & $12,324,811$ \\
Loop (Loop) & $4,482,016$ & $1,462,000$ & $5,944,016$ \\
Next Door (Naboer) & $15,860,000$ & $2,500,000$ & $18,360,000$ \\
Grandpa is a Raisin (Nå skal du høre) & $2,673,979$ & $1,001,212$ & $3,675,191$ \\
Pitbullterje (PitbullTerje) & $17,407,826$ & $5,444,400$ & $22,852,226$ \\
Sinus (Sinus) & $4,734,684$ & $1,700,370$ & $6,435,054$ \\
The Professor and the Story & & & \\
of the Origami Girl (Origamijenta) & $2,551,904$ & 760,000 & $3,311,904$ \\
Tommy's Inferno (Tommys inferno) & $13,720,000$ & $3,446,533$ & $17,166,533$ \\
Finding Friends (Venner for livet) & $14,671,146$ & $2,200,000$ & $16,871,146$ \\
Kissed by Winter (Vinterkyss) & $15,208,109$ & $2,091,212$ & $17,299,321$ \\
Average & $11,871,414$ & $2,428,901$ & $14,300,315$ \\
\hline
\end{tabular}

Source: Norwegian Film Fund.

The catalyst financing provided by public sources was thus very strong, covering more than half of the aggregate costs for all of the 2005 films.

Table 2. Average Film: Public and Private Finance

\begin{tabular}{lrrrrrr} 
Source & \multicolumn{2}{c}{ Production } & \multicolumn{2}{c}{ P\&A } & \multicolumn{2}{c}{ Total } \\
\hline Film Fund & $5,429,051$ & $45.7 \%$ & 803,399 & $33.1 \%$ & $6,232,450$ & $43.6 \%$ \\
Other Public Funding & $1,240,567$ & $10.5 \%$ & 70,390 & $2.9 \%$ & $1,310,957$ & $9.2 \%$ \\
Equity Capital & $5,201,796$ & $43.8 \%$ & $1,555,112$ & $64.0 \%$ & $6,756,907$ & $47.3 \%$ \\
Total & $11,871,414$ & $100.0 \%$ & $2,428,901$ & $100.0 \%$ & $14,300,315$ & $100.0 \%$ \\
\hline
\end{tabular}

\section{Sources of Private Finance}

The structure of private financing varied significantly between the 19 films, but on average more than three quarters came from producer, distributor and the use of deferred payments. The insider element in private financing was thus very strong.

The exact breakdown of the private funding was made into the following categories with key numbers presented in Table 3 and 4 below:

Producer: This is the cash investment made by the film's production company or companies if more than one was involved, which typically takes the form of an equity investment. The producer's contribution to the financing was in some cases bigger than reflected in these numbers, as the producer sometimes also deferred a share of its budgeted fees. 
Distributor: This is the cash investments made by the film's distribution company. They are typically made in the form of MGs, but some are also made as equity investments. Some distributors also contributed deferments towards the P\&A budget in addition to their cash investment and such deferments are not included here.

Deferments: These are budgeted production and P\&A costs that are paid on a delayed basis out of the film's revenues rather than out of the budgets. In addition to the producer and distributor, deferments were made by production and post-production service companies, suppliers and key personnel such as writers, directors and cinematographers.

TV pre-sales: Some of the producers sold the television distribution rights before their film went into production and used the license fees to cover part of their private capital.

$T V$ investment: Two of the films had direct equity investments into the production from television companies. In one case, the investment was combined with a pre-sale, splitting the television company's financial contribution into a pre-sale and an investment part. In the other case, the full financial contribution was defined as an investment with no pre-sale recorded, but the TV company took co-producer status that likely secured television distribution rights.

Foreign investment: These are investments made from a variety of foreign sources, but the primary sources were foreign co-producers and partners, distributors and television companies. The category thus largely represents the foreign equivalent to the producer, distributor and TV categories above.

Table 3. Average Film: Sources of Private Capital

\begin{tabular}{lrrrrrr} 
Source & \multicolumn{2}{c}{ Production } & \multicolumn{2}{c}{ P\&A } & \multicolumn{2}{c}{ Total } \\
\hline Producer & 957,666 & $18.4 \%$ & 264,004 & $17.0 \%$ & $1,221,670$ & $18.1 \%$ \\
Distributor & $1,525,173$ & $29.3 \%$ & $1,082,863$ & $69.6 \%$ & $2,608,037$ & $38.6 \%$ \\
Deferments & $1,322,089$ & $25.4 \%$ & 99,339 & $6.4 \%$ & $1,421,427$ & $21.0 \%$ \\
TV pre-sales & 166,842 & $3.2 \%$ & 19,222 & $1.2 \%$ & 186,064 & $2.8 \%$ \\
TV investment & 278,947 & $5.4 \%$ & 0 & $0.0 \%$ & 278,947 & $4.1 \%$ \\
Foreign & 743,327 & $14.3 \%$ & 0 & $0.0 \%$ & 743,327 & $11.0 \%$ \\
Other & 207,751 & $4.0 \%$ & 89,684 & $5.8 \%$ & 297,436 & $4.4 \%$ \\
Total & $5,201,796$ & $100.0 \%$ & $1,555,112$ & $100.0 \%$ & $6,756,907$ & $100.0 \%$ \\
\hline
\end{tabular}

Table 4. Private Capital Spread for the 2005 Films

\begin{tabular}{lccr} 
Source & Low & High & Average \\
\hline Producer & $0 \%$ & $57 \%$ & $18 \%$ \\
Distributor & $0 \%$ & $82 \%$ & $39 \%$ \\
Deferments & $0 \%$ & $67 \%$ & $21 \%$ \\
TV pre-sales & $0 \%$ & $24 \%$ & $3 \%$ \\
TV investment & $0 \%$ & $73 \%$ & $4 \%$ \\
Foreign & $0 \%$ & $60 \%$ & $11 \%$ \\
Other & $0 \%$ & $21 \%$ & $4 \%$ \\
\hline
\end{tabular}

\section{Layering}

The financing structure of all the films had some element of layering, but varied from relatively simple structures to more sophisticated use of layering. However, the more 
advanced structures typically incorporated the basic elements of the simpler structures and one can thus see some overall common patterns.

One common element was the financing provided by the Norwegian Film Fund. Repayment of monies provided by the Fund for production and/or P\&A costs were only due to start once the project had recouped an amount equal to 130 percent of its private capital, and at that point the share due to the Fund equaled only 30 percent of its financing share. For instance, if the Fund had financed 50 percent of a NOK 10 million film, where the remaining share was covered by private capital, repayments to the Fund would only start once the project had earned NOK 6.5 million, and then only with 15 percent of the revenues received from then on going forward. The financing provided by the Fund was thus deeply subordinated to other sources of funding, in line with its role as a project "catalyst".

Financing provided by distributors was another common element with relatively minor variance from project to project. The distributor's financing was typically provided in the form of an MG with full repayment due off-the-top in an exclusive first priority position ahead of any other financier. Furthermore, the distributor would typically be granted distribution rights to more than one media outlet or window (e.g. theatrical and home-video) with the right to cross-collaterize revenues so that ancillary market income would be fully allocated to recoup the MG should it not be covered by theatrical revenues.

The Norwegian Film Fund and distributors thus generally defined a bottom and top layer in each film's financing, as illustrated in Figure 6.

Figure 6. Common Layering for the 2005 Films

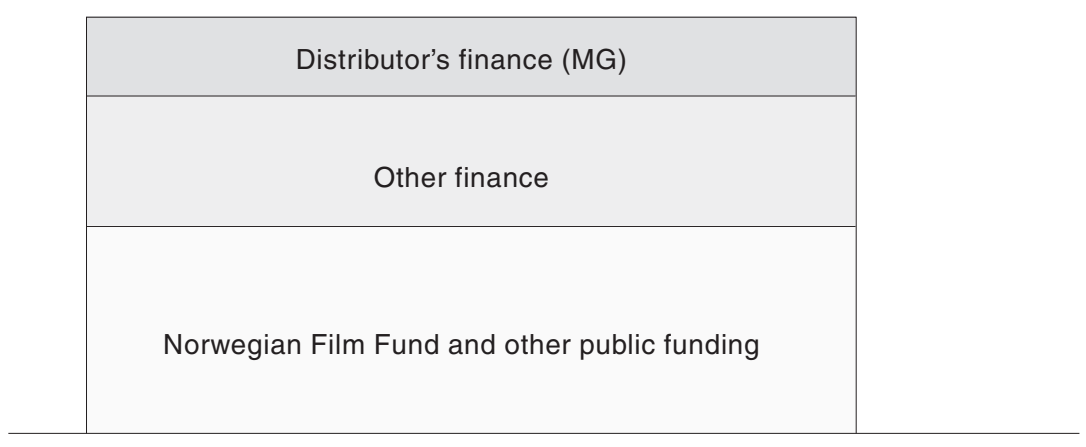

In between these common upper and lower layers, the variance seemed to be greater, and due to incomplete data also more difficult to map.

\section{The Norwegian 2005 Films: Performance}

The overall theatrical performance of Norwegian national films in 2005 was slightly weaker, but at the same level as the previous and following years. Of the total theatrical gross income, the share held by national films was 12.5 percent, and of a total of 230 films released that year, 20 were Norwegian (including one reissued film excluded from this study) (Film \& Kino 2006). Yet, in line with the conclusions drawn by DeVany and Walls (1999) concerning motion picture market behavior, the performance varied dramatically 
from one film to another with some performing very well and earning strong profits, while others failed to find an audience and thus returned great losses to their investors.

\section{Sources of Income}

The main sources of income for national films include both the usual sources of market revenues and automatic public funding from the Norwegian Film Fund in the form of box office bonuses. The market revenues were split in two categories:

Theatrical revenues: The theatrical gross income from ticket sales (the box office) is split between cinema owners and distributors, and the distributor's share (the film rental) is split between distributor and producer. The producer's share goes into the project pot for servicing and recouping project financing. The producer's theatrical revenues are calculated as 25 percent of the total box office gross ${ }^{10}$.

Ancillary revenues: This category includes all revenues earned by the producer from exploitation of the film in all other markets, including home-video (DVD), pay and free $\mathrm{TV}$, new media and foreign sales. For the present study, it was assumed that revenues from ancillary markets constitute 50 percent of producer's total market revenues, i.e. that ancillary revenues equal producer's theatrical revenues ${ }^{11}$.

While all market earnings are calculated based on reported revenues in only one market, the domestic theatrical market, the actual revenues reported to the Film Fund for eight of the films suggest that the calculated figures are quite accurate compared to actual figures. Total calculated revenues for these eight films were only 5.5 percent over the actual reported revenues.

The box office bonuses paid out by the Norwegian Film Fund to the producers equal 55 percent of the film's gross box office and are paid out up until the film's private capital plus overhead have been recouped from market revenues and box office bonuses. The actual bonus figures paid out to the 19 films were provided by the fund.

For the average film, box office bonuses accounted for 53 percent of producer's total revenues, while theatrical and ancillary markets accounted for 23.5 percent each.

Table 5. Average Film: Sources of Revenues

\begin{tabular}{lrr}
\hline Producer's theatrical revenues & $1,276,942$ & $23.5 \%$ \\
Producer's ancillary revenues & $1,276,942$ & $23.5 \%$ \\
Film Fund Box Office Bonuses & $2,873,705$ & $52.9 \%$ \\
Total & $5,427,589$ & $100.0 \%$ \\
\hline
\end{tabular}

\section{Return on Capital}

Generally one would not expect a positive return on capital for a Norwegian film. With the limited size of its home market and facing a significant cultural discount in foreign markets, ${ }^{12}$ it has proven very difficult for national films to generate revenues sufficient to cover their production and distribution costs.

The simple measurement for return on capital used here is the ratio of money gained or lost relative to the money invested in each film project; where the money invested refers to the total budget. It is not annualized or in any other way adjusted to the time period the investment is held. 
Aggregate figures for all 19 films show a loss of 62 percent, meaning that of the total NOK 272 million invested into the films by private and public parties, NOK 169 million were left uncovered by aggregate revenues. The average film with a budget of NOK 14.3 million would incur a loss of NOK 8.9 million.

However, there is no typical or average film, because box office revenue outcomes do not converge to an average (DeVany and Walls 1999), and this is of course reflected in the return on capital figures. The significant spread in return on capital among the 19 films released in 2005 is shown in Figure 7 below. The return ranges from a seven percent gain to a 97 percent loss. The best performing film, which could show the seven percent gain, was the only film with a positive return on its total capital. All other showed losses. Fourteen films lost more than 50 percent and six films showed losses of more than 90 percent.

\section{Return on Private Capital}

To examine why participation from the traditional investment community in film financing is lacking, a more relevant measure may be to look at the return on private capital. Of the aggregate figures, private capital represents 47 percent of the total budgets or the total capital, with a range among the individual films from 25 to 89 percent. And it is the return on this capital that is the decisive factor for a potential investor in the traditional investment community who is considering participation in a national film.

When calculating the return on private capital, it is assumed that all private capital takes a priority position in the waterfall recoupment not only to the financing provided by the Norwegian Film Fund, but also to all other public funding. It is furthermore assumed that the public funding is non-recoupable. Repayments are so minor and only affect the most successful films, so omitting such repayments here does not have any significant effect on the whole picture. Finally, it is assumed that all types of private capital are recoupable at 100 percent of the amount invested in the film. This latter assumption creates a simplified picture of the real world, as some funding for instance may be recoupable with a fixed mark-up (e.g., 120 percent of the amount invested) and some contributions may not be recoupable but made in consideration of certain rights (e.g., TV pre-sales). Still, such adjustments are relatively minor and primarily related to the division of cash flow among private capital providers, so the return on private capital calculations thus provides a fairly accurate measure of the overall gains and losses incurred for the private capital invested into the 19 films.

With private capital taking a priority position to public funding, the return is considerably better than for the total capital. Aggregate figures for all 19 films show a loss of 20 percent as opposed to the 62 percent loss for total capital. Of the NOK 128 million put into the 19 films as private capital, NOK 25 million were lost.

Again, results for individual films varied greatly. While the best performing film could return a strong 92 percent gain ${ }^{13}$ to its private capital investors, the worst performing film produced a loss of 95 percent. Five of the 19 films had positive returns, all showing gains above 35 percent. The rest, however, lost money for their private capital investors. Ten lost 50 percent or more, and eight produced losses of 75 percent or more (see Figure 7). 


\section{Public Funding Effects on Private Capital Return}

The public funding affects the return on private capital in two ways. First, the direct public production and $\mathrm{P} \& \mathrm{~A}$ funding is taking a subordinated position to private capital in the layered financing, and second, the box office bonuses greatly increase revenues.

The layering effects on distribution of revenues and thus on distribution of gains and losses are already illustrated in the previous two sections. By taking a subordinated position to private capital, public funding bodies greatly improve the return on capital for private investors. If private and public capital had not been layered, but treated on an equal pro-rata basis, private investors in the best performing film would only have seen a modest return of seven percent instead of the very healthy 92 percent gain obtained when given priority. And it would only have been the private investors in this single film that would have seen any positive return on their investments, instead of all private investors in the five best performing films who saw positive returns with this simple layering (see Figure 7).

Without the box office bonuses, revenues for the average film would be cut in half with severe effects on private capital returns. Even with the subordinated direct public funding in place, return on private capital would have dropped from an aggregate 20 percent loss to a 62 percent loss. The best performing film would have returned a nine percent profit instead of 92 percent. All other films would have produced negative returns, and 15 of the 19 films would have lost more than half of their private capital (see Figure 7). Dropping the box office bonuses from total revenues would have increased the aggregate loss of total capital (including public funding) from 62 percent to 82 percent.

\section{Layering and Distribution of Losses}

As discussed above, also the private capital is typically layered so not all private investors are exposed to the same combinations of risks and rewards. A film's distributor typically takes an exclusive first priority position for its investment. Assuming that all distributors of the 2005 films took such a priority position for all their private capital contributions, ${ }^{14} \mathrm{a}$ top layer of distribution investments may be separated from the private capital layer (see Figure 6 above).

For the average film where the distributor contributes 39 percent of the private capital, such priority layering would reduce its loss from 20 percent to zero. For all other providers of private capital, however, taking a subordinated position to the distributor would increase the loss from 20 to 32 percent.

Applying this layering, the distribution of losses among distributors and other private capital investors for the 19 films are shown in Figure 8 below. Generally, losses are shifted from distributors onto other private investors. The distributors, which invested in 18 of the 19 films, would incur zero losses in 11 films. For five films, the distributor would lose between one and 49 percent of its investment, and for two films the loss would be between 50 and 99 percent. For none of the films, the distributor would lose its full investment. Other private investors, however, would now only avoid losses for five films, lose between one and 49 percent in three films, between 50 and 99 percent in four films, and for seven films their full investments would be lost. Without this layering, no private investor would have lost its full investment. 


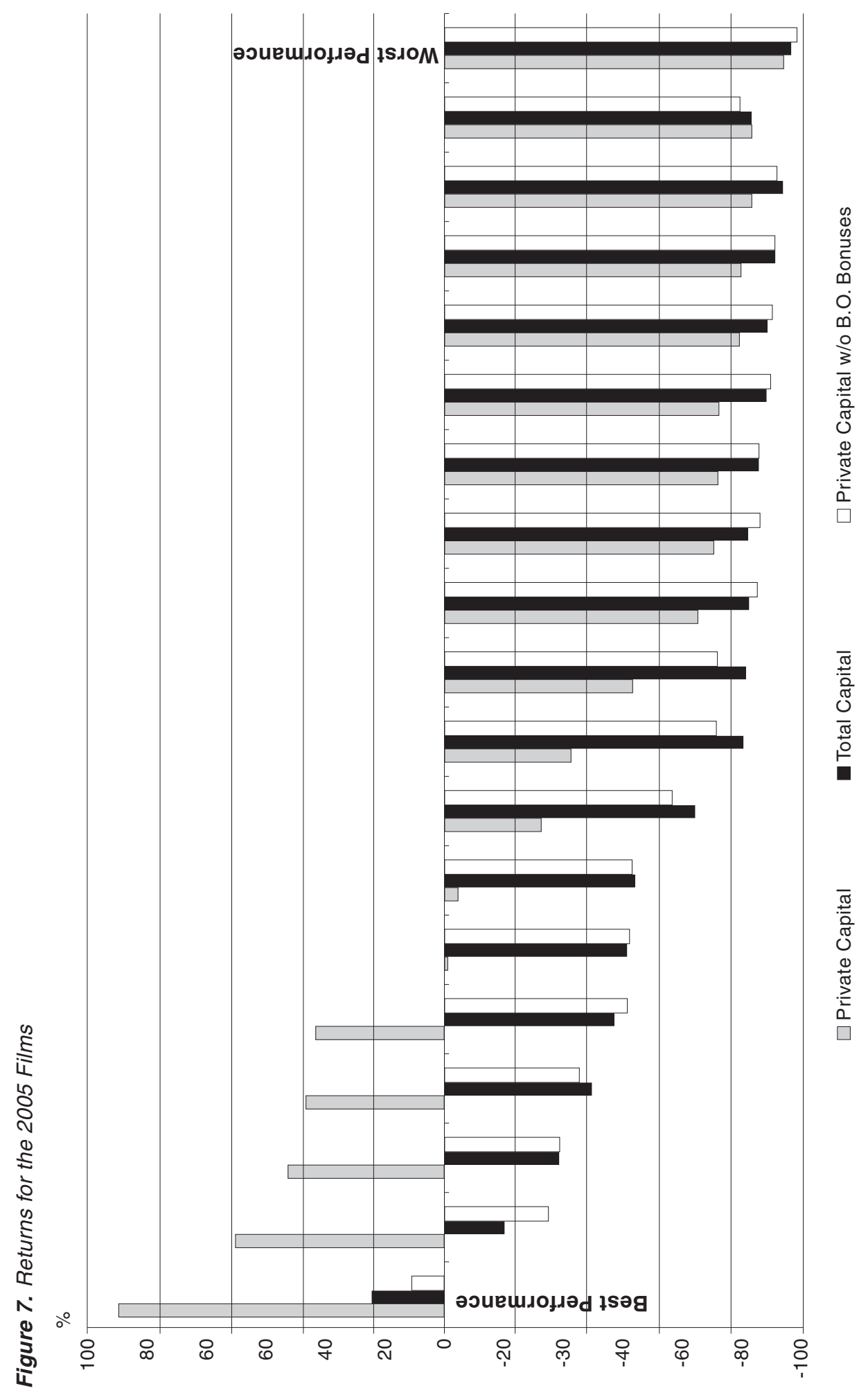




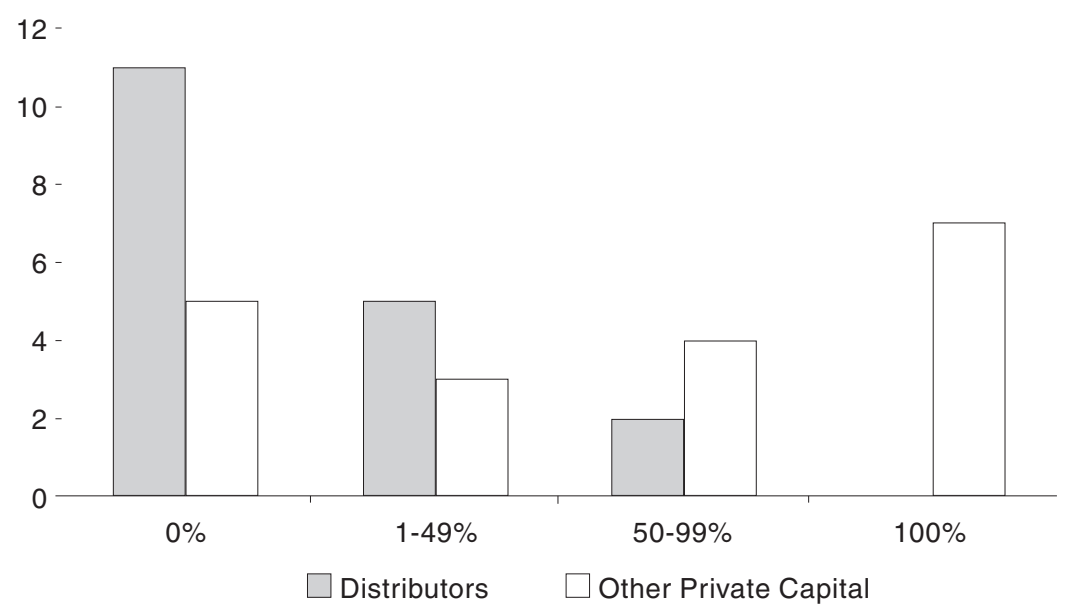

This shows how distributors, who are the largest contributor of private capital to Norwegian films, largely avoid losses by insisting on a lower-risk first priority position for their investments. A significantly higher risk and a larger share of the losses are taken by other private investors, but they may of course compensate by demanding a larger share of potential gains.

\section{Concluding Remarks}

The importance of public funding for private film financing in a small country like Norway is evident when we compare the return on total capital with the return on private capital. An average loss of 20 percent on private capital is modest compared to the 82 percent loss faced when public funding is taken out of the equation. If Norwegian filmmakers were to lose their public funding - ceteris paribus - they would most likely no longer be able to attract private financing either.

Still, with what may be regarded as a generous public funding system, Norwegian filmmakers struggle to attract private financing from the traditional investment community. The findings presented above indicate at least three possible reasons why these investors may be hesitant to participate in feature film financing: An overall negative return on private capital, extreme performance outcomes for the individual projects and a possible transaction cost issue tied to volume.

First, the aggregate figures for all 2005 films show a negative return on private capital of 20 percent. Generally, capital is drawn to the investment opportunities offering the best return, and it is thus likely that traditional investors will pay more attention to other sectors of the economy that can offer better profitability.

Looking solely at this overall return figure, the question becomes less why investors from the traditional financial community stay out, but rather why industry insiders choose to invest. In addition to other reasons discussed below, one reason may in many cases be that industry insiders have other motives for their investment decision than only the expected financial return on investment. Suppliers as well as crew and cast may for 
instance accept partially deferred fees in order to participate in a project so that they can build their reputation and network ${ }^{15}$.

Second, the distribution of performance outcomes among the films does not converge to an average, and extreme outcomes are common. That some films may show healthy return on capital above 50 percent, as noted in the 2004 government white paper (St. meld. Nr. 25, 2003-2004), does not provide any strong indication of the general level of return under such conditions. The underlying uncertainty is creating a high level of investment risk, and this may discourage potential traditional investors. Significant losses for single projects are not unlikely.

Finally, relatively low volume transactions with potentially high transaction costs may be a problem. Each investment is seldom above NOK 2 million and often below one million, generally at a level that may be low for many professional investors. This coupled with high transaction costs creates a situation where a strong return is required just to recover the costs associated with making the investment. High ex ante transaction costs, particularly evaluation and contracting costs, may be expected, as the distribution of performance outcomes creates very strong incentives for trying to pick the winners ${ }^{16}$.

So how can industry outsiders be attracted to invest in national feature films? One may attract outsider investments by improving public funding further (increased production funding, relaxed repayment terms, higher box office bonuses, etc.), but it is hardly a feasible solution as long as the political goal is to skew the ratio between public and private funding in favor of private participation. The key may instead lie with the industry insiders. Through more sophisticated use of layering, producers may find structures containing investment opportunities that better fit the risk and return appetites of investors within the traditional financing community. The analysis presented here shows how risk is reduced for priority-layer investors when adding subordinated layers. If relatively risk-averse outside investors are offered some form of priority position debt financing (gap deals or similar), ideally combined with further efforts to reduce transaction costs (see Williamson 1988), they may accept. Hence, the insider's dilemma may be that attracting outsiders willing to carry part of the financing can only be done at the cost of increased risk for the share insiders are left to carry themselves.

\section{Notes}

1. See Williamson (1985) and Rindfleisch and Heide (1997) for an introduction.

2. Project financing is part of the broader defined area of structured finance (Davis 2005).

3. It can also represent a slate of projects or finished films. Raising project financing on a slate of films seems to be an increasingly popular financing tool used by the bigger Hollywood-based film companies (Eisbruck 2005)

4. See Helgesen and Gaustad (2002), Chapter 8, for an overview of distribution rights.

5. Financial closure is the point at which the project participants reach a formal agreement on the fundamental business structure of the project and the project's financing plans (Merna and Khu 2003).

6. An independent film is understood as a film made outside the control of a major integrated productiondistribution company, such as the Hollywood studios.

7. An interest reserve account for the gap loan is often built into the production budget as a financing cost, but still it may also be added as a separate item in the cash waterfall in a position above the repayment of the loan.

8. These include two films ("Grandpa is a Raisin" and "The Professor and the Story of the Origami Girl") with a running time less than the 72 minutes minimum required in the Film Fund's feature definition, but the two films were still given independent theatrical releases and are thus of similar interest in terms of finance and market performance as the true features. 
9. Foreign $\mathrm{P} \& \mathrm{~A}$ is not included in the financing.

10. This is the same share as used by the Norwegian Ministry of Culture and Church Affairs in their calculations.

11. The Norwegian Film and Television Producers' Association has indicated that the ancillary share may be as high as 82 percent (St. meld. nr. 25, 2003-2004).

12. For a discussion of cultural discount effects, see, e.g., Hoskins et al. (1988)

13. Incorporating repayment of public funding in line with film fund requirements at the time, the return on private capital would have been 83 percent for this film. For the other four profitable films, public funding repayment would have had a significantly lesser effect.

14. At least one distributor accepted part of its investment in a second priority layer pro-rata with equity investors (see Figure 3.5), so this assumption provides a slightly simplified picture of the actual layering of distributors finance.

15. For discussions of non-financial rewards, see Blair and Randle (2003) and Cowen and Tabarrok (2000).

16. Research cannot identify or support any method for achieving this (DeVany and Walls, 1999).

\section{References}

Baumgarten, P.A.; Farber, D.C., \& Fleischer, M. (1992) Producing, Financing and Distributing Film: A Comprehensive Legal and Business Guide. New York, NY: Limelight Editions.

Blair, H.; Culkin, N., \& Randle, K. (2003) 'From London to Los Angeles: A Comparison of Local Labour Market Processes in the US and UK Film Industries', International Journal of Human Resource Management, 14(4): 619-633.

Cones, J.W. (1992) Film Finance \& Distribution: A Directory of Terms. Los Angeles, CA: Silman-James Press.

Cones, J.W. (1997) The Feature Film Distribution Deal: A Critical Analysis of the Single Most Important Film Industry Agreement. Carbondale, IL: Southern Illinois University Press.

Cowen, T. \& Tabarrok, A. (2000) 'An Economic Theory of Avant-Garde and Popular Art, or High and Low Culture', Southern Economic Journal, vol. 67(2), 232-253.

DeVany, A. \& Walls, W.D. (1999) 'Uncertainty in the Movie Industry: Does Star Power Reduce the Terror of the Box Office?', Journal of Cultural Economics, vol. 23, 285-318.

Film\&Kino (2007) Facts and Figures 2006. Oslo: Film \& Kino.

Film\&Kino (2006) Facts and Figures 2005. Oslo: Film \& Kino.

Helgesen, T. \& Gaustad, T. (2002) Medieøkonomi: strategier, markedsføring, medierettigheter. Nesbyen: Stølen, kap. 8

Hoskins, C.; Mirus, R. \& Rozeboom, W. (1988) 'Reasons for the US Dominance of the International Trade in Television Programmes', Media, Culture \& Society, 10, 499-515.

Le Floch-Andersen, L. (1999) Public Aid Mechanisms for the Film and the Audiovisual Industry in Europe, 1995-1999. Strasbourg: European Audiovisual Observatory.

Marna, T. \& Khu, F. (2003) "The Allocation of Financial Instruments to Project Activity Risks", Journal of Structured \& Project Finance, vol. 8 (4), 2134.

Parra, R.J. \& M. Kahn (2001) 'Layered Finance', Journal of Structured \& Project Finance, vol. 7 (3), p $49-61$

Pendreigh, B. (2003) 'Banking on a Captive Audience', The Sunday Herald, January 26, 2003.

Rindfleisch, A. \& Heide, J.B. (1997) 'Transaction Cost Analysis: Past, Present, and Future Applications', Journal of Marketing, vol. 61 (October 1997), 30-54.

Rudman, N.G. \& Ephraim, L.A. (2004) 'The Finishing Touch: The Completion Guarantee', in Squire, J.E. (ed.) The Movie Business Book. New York, NY: Fireside.

SBB (2008) Population: Key Figures [online] Oslo: Statistics Norway. Available from URL: http://www.ssb. no/english/subjects/02/befolkning_en/. Accessed January 28, 2008.

St. meld. nr. 25 (2003-2004), Økonomiske rammebetingelser for filmproduksjon. Norwegian Ministry of Culture and Church Affairs. Oslo, Norway.

St. meld. nr 22 (2006-2007) Veiviseren. Norwegian Ministry of Culture and Church Affairs. Oslo, Norway.

Williamson, O.E. (1985) The Economic Institutions of Capitalism: Firms, Markets, Relational Contracting. New York, NY: The Free Press.

Williamson, O.E. (1988) 'Corporate Finance and Corporate Governance', Journal of Finance, vol. 43 (3), 567-91.

TERJE GAUSTAD, M.A., Senior Lecturer, Department of Communication, Culture and Languages, BI Norwegian School of Management, Oslo, Norway, terje.gaustad@bi.no 